\title{
KEMISKINAN DAN PENGARUHNYA TERHADAP MOTIVASI DAN PRESTASI BELAJAR ANAK-ANAK DI KOTA LANGSA
}

\author{
Basri Ibrahim \\ Sekolab Tinggi Agama Islam Negeri (STAIN) Zawiyah Cot Kala Langsa \\ stain_zck@yahoo.com
}

\begin{abstract}
This research is intended to discuss the influence of poverty toward children learning motivation and explain the relation among motivation toward academic achievement in poor family in Langsa. Quantitative method being applied on this research shows that the influence of poverty towards student academic achievement tends to be solid, so that the students education level are influenced by their family economic background. Moreover this condition will also influence the student learning motivation. Finally, the family with poverty tend to ignore their children education due to their daily needs is more important than thir children education
\end{abstract}

Keywords: Poverty, Learning motivation, Academic achievement

\begin{abstract}
Abstrak
Artikel ini memaparkan pengarub kemiskinan terhadap motivasi belajar anak-anak di Kota Langsa. Selanjutnya menjelaskan bubungan motivasi terhadap prestasi akademik siswa di Kota Langsa dari keluarga kurang mampu. Dengan menggunakan metode kuantitatif melalui uji statistik ditemukan bahwa pengarub kemiskinan terhadap motivasi dalam pencapaian prestasi belajar siswa di Kota Langsa sangat kuat. Dari hasil tersebut didapat sebuab kesimpulan bahwa tingkat pendidikan anakanak dipengarubi oleb tingkat kemampuan ekonomi keluarganya sebingga memberi pengarub pada motivasi belajar siswa. Keluarga yang kondisi ekonomi lemab cenderung mengabaikan pendidikan anakanaknya karena pemenuban kebutuhan sehari-hari dalam keluarga lebih penting dari pendidikan anaknya.
\end{abstract}

Kata kunci: Kemiskinan, motivasi belajar, prestasi akademik 


\section{Pendahuluan}

Kemiskinan sudah menjadi fenomena sepanjang sejarah kemanusiaan. Indonesia sebagai salah satu Negara yang kaya sumberdaya alamnya namun tidak terlepas dari persoalan kemiskinan, akibat adanya salah memahami dan mengurus kemiskinan. Konsekwensinya telah membuat jutaan anak-anak Indonesia tidak bisa mengenyam pendidikan yang berkualitas, membiayai kesehatan, ketiadaan tabungan dan tidak ada investasi, tidak ada akses pelayanan ke publik, kurangnya lapangan pekerjaan, kurangnya jaminan sosial, kurangnya perlindungan terhadap keluarga, menguatnya arus urbanisasi ke kota. Implikasi lebih jauh kemiskinan telah membuat jutaan rakyat tidak dapat memenuhi kebutuhan pangan, sandang dan papan. Pemerintah Indonesia secara berkesinambungan terus melaksanakan berbagai program untuk meningkatkan kesejahteraan rakyat melalui serangkaian penanganan permasalahan fakir miskin dalam rangka memberdayakan keluarga miskin, karena fakir miskin dan anak-anak terlantar harus dipelihara oleh Negara (UUD. RI 1945 pasal 34).

Berbagai peraturan perundangan dan kebijakan pada level nasional dan internasional menempatkan anak sebagai kelompok usia yang rentan sehingga perlu diberi perlindungan. Karena secara kognitif, anak belum matang dalam menganalisa suatu situasi, belum banyak memiliki pengalaman atau pengetahuan, dan belum mampu mengambil keputusan terbaik. Secara fisik tentu kita memahami anak memiliki kekuatan dan bahkan anak yang usianya lebih muda memiliki daya tahan tubuh yang tidak sebaik orang dewasa. Secara sosial, anak masih memiliki keterbatasan dalam mengungkapkan pikiran dan perasaannya kepada orang lain. Keterbatasan tersebut membuat mereka sangat tergantung pada orang dewasa baik secara fisik, untuk memenuhi kebutuhan dasar, maupun psikososial, untuk memenuhi kebutuhan emosional dan sosial.

Kondisi anak yang rentan membuat para peneliti sebelum era 1950-an banyak yang mengkaji faktor-faktor risiko baik dari sisi biologis maupun psikososial sehingga seorang anak memiliki permasalahan tumbuh kembang atau tumbuh menjadi orang dewasa yang maladaptif (Werner, 2005). Saat itu banyak penelitian-penelitian 
retrospektif dilakukan dengan merekonstruksi sejarah hidup dan pengalaman mereka yang menjadi kriminal, memiliki kesulitan belajar di sekolah dan sebagainya. Didapatlah faktor-faktor risiko seperti pengalaman traumatik, kemiskinan, orangtua, dan sebagainya yang menjadi penyebab seseorang tumbuh menjadi pribadi yang tidak kompeten dan maladaptif.

\section{Kemiskinan}

Kemiskinan dalam pengertian yang paling sederhana adalah kurangnya kepemilikan uang (Suyanto dalam PBS 2007), dalam arti yang lebih luas dan lebih relevan untuk didiskusikan sehubungan dengan gangguan mental dan tingkahlaku, kemiskinan adalah keadaan kurangnya alat, termasuk kurangnya sumberdaya sosial atau pendidikan. Kemiskinan dan keadaan yang terkait seperti pengangguran, pendidikan yang rendah, tidak mempunyai tempat tingal dan tidak memiliki apa-apa bukan hanya berlaku di negara miskin tapi juga pada minoritas di negara maju (BPS; 2007).

Kemiskinan juga merupakan penghantar dari berbagai variabel yang memperbesar resiko kegagalan atau ketidakmampuan. Kondisi ini secara tidak langsung memperbesar resiko perkembangan anak melalui: perawatan prenatal, gizi buruk, serta taraf pendidikan yang rendah. Anggota masyarakat yang sangat rentan oleh kondisi ini adalah anak dan perempuan (Brackenreed, 2010). Banyak sekali anak harus hidup dalam kondisi yang berdampak buruk, baik secara fisik maupun kognitif, pada anak diakibatkan oleh kemiskinan. Fujiura dan Yamaki, serta Seelman dan Sweeney (dalam Brackenreed, 2010) menyatakan bahwa lingkungan tempat anak dibesarkan memiliki peran yang sangat penting bagi perkembangan kognisi, fisik dan psiko-sosial anak.

West and Farrington (dalam Brackenred, 2010), dalam penelitian mereka terhadap anak-anak yang bermasalah pada tahun 1991 juga menemukan bahwa pendapatan keluarga yang sangat rendah merupakan salah satu resiko yang paling potensial disamping beberapa masalah lain terhadap terbentuknya masalah pada anak. Pada tahun 2010 ditemukan bahwa masalah tersebut masih merupakan momok yang menempatkan anak-anak pada kondisi 
yang rentan terhadap kegagalan pendidikan dan dalam kehidupan secara luas meskipun berbagai usaha telah dilakukan untuk mengatasinya (Brackenreed, 2010).

Teori Drift menjelaskan tentang gangguan psikotik dan penggunaan narkoba dikalangan orang miskin, namun keduanya tidak terpisah sama sekali satu dan lain: individu dapat berpotensi mengalami masalah mental kerana mereka miskin, dan orang boleh saja menjadi papa kerana mereka sakit, contohnya: kerena mengalami abnormalitas mental maka orang menjadi rendah tingkat pendidikannya, pengangguran, dan menjadi tunawisma, ada juga bukti yang menunjukkan bahwa perjalanan gangguan mental dan tingkah laku ditentukan oleh status sosial ekonomi dari individu. (WHO, 2001).

Lebih lanjut kalau kita telusuri penyebab kemiskinanan terdapat tiga faktor utama. Pertama, terkait dengan wilayah bencana (disaster prone area) dipercayai sebagai penyebab yang menjadi sebab kemiskinan dalam setiap negara, kemiskinan selalu menjadi problem sosial yang menjadi tolok ukur keberhasilan pembangunan, akan tetapi bencana dipercayai sebagai sebab utama dari faktor kemiskinan dimana orang-orang yang terkena dengan berbagai peristiwa bencana sangat rentan terhadap kemiskinan, kekeringan seperti yang telah melanda beberapa negara di Afrika, banjir, peperangan, tsunami dan berbagai faktor alam lainnya telah membuat setiap orang yang dekat kepada peristiwa tersebut kehilangan harta benda.

Peristiwa bencana terbagi kepada dua bentuk, yaitu akibat ulah manusia dan akibat alamiah (sunnatullah). Bencana yang disebabkan oleh ulah manusia seperti konflik, ketidakstabilan politik, korupsi yang terlalu besar telah menyebabkan kemiskinan di berbagai belahan bumi. Sedangkan bencana yang disebabkan oleh faktor alam seperti tanah longsong, banjir, tsunami, banjir bandang, kebakaran, dan lain sebagainya yang datang dari alam.

Kedua, faktor kebijakan atau struktural seperti kebijakan ekonomi yang tidak adil. Dalam sebuah Negara suku bunga bank yang tinggi, susahnya mendapat pinjaman modal, nilai mata uang yang rendah, subsidi pemerintah yang kecil dan tidak tepat, sistem 
pemberian upah pada buruh yang rendah, dan tidak adanya subsidi pemerintah dalam pendidikan dan kesehatan dipercayai sebagai faktor umum yang menjadi penyebab utama kemiskinan.

Ketiga, faktor mental. Mental yang lemah memiliki potensi sebagai penyebab kemiskinan. Mental dan tingkahlaku, termasuk gangguan penggunaan narkoba, tentang mengapa masalah kesehatan mental cukup tinggi dikalangan orang miskin menuai perdebatan apakah kemiskinan yang menjadi pokok permasalahan orang mengalami ganguan kesehatan mental (causal mechanism) atau karena memiliki mental orang menjadi miskin (drift mechanism), tampaknya kedua alasan tersebut relevan. Pattel, WHO (2001), menjelaskan faktor pendidikan yang rendah pada setiap individu dapat berpotensi mengalami masalah mental karena mereka miskin, dan orang bisa saja menjadi papa karena mereka sakit, contohnya: kerena mengalami abnormalitas mental orang menjadi rendah tingkat pendidikannya, pengangguran, dan menjadi tunawisma, ada juga bukti yang menunjukkan bahwa perjalanan gangguan mental dan tingkah laku ditentukan oleh status sosial ekonomi dari individu.WHO, (2001).

Jelas bahwa kemiskinan tidak berdiri sendiri dengan dampak yang negatif bagi anak-anak. Kemiskinan di Aceh adalah sebuah fakta yang tak terhindarkan meskipun daerah ini sangat kaya sumber daya alam yang terkandung didalamnya namun Aceh merupakan "disasterprone area, wilayah rentan bencana. Ditambah lagi dengan kebijakan pemerintah yang memperparah kemiskinan di Aceh secara struktural. Badan Pusat Statistik Provinsi (BPS) Aceh mengeluarkan data jumlah penduduk miskin tingkat kemiskinan Aceh tahun 2010 yang dipublikasikan dalam www.aceh.bps.go.id yang memaparkan bahwa jumlah penduduk miskin di Aceh pada tahun 2010 sebesar 861,85 ribu jiwa atau 20,98 persen. Jika dibandingkan dengan penduduk miskin pada tahun 2009 yang berjumlah 892,86 ribu jiwa atau 21,80 persen maka jumlah penduduk miskin di Aceh menurun hingga 0,82 persen. Jika dihitung kedalam angka pendapatan perkapita per bulan, angka garis kemiskinan pada tahun 2009 sebesar Rp.261.898 perkapita/bulan meningkat menjadi Rp 278,389 perkapita/bulan untuk tahun 2010. 
Sementara tingkat kemiskinan di Kota Langsa, BPS Aceh menyatakan bahwa jumlah penduduk miskin di Kota Langsa pada tahun 2010 sebesar 22,4 ribu jiwa atau 15,0 persen, dan jika dibandingkan dengan jumlah penduduk miskin Kota Langsa pada tahun 2009 sebesar 21,3 ribu jiwa atau 16,2 persen, maka jumlah ini meningkat sebesar 1,2 persen ketahun 2010. Jika dihitung kedalam angka pendapatan perkapita per bulan, angka garis kemiskinan pada tahun 2009 sebesar Rp. 248,283 perkapita/bulan meningkat menjadi Rp 270,201 perkapita/bulan untuk tahun 2010.

Kondisi kemiskinan telah mengakibatkan berbagai persoalan psikologis bagi masyarakat Aceh sebab dari ketidak berdayaan akan mengakibatkan tekanan yang akan mempengaruhi motivasi belajar anak-anak. Apabila kondisi kemiskinan ini melibatkan pelajar maka akan berefek terhadap hasil akhir pendidikan (prestasi akademik pelajar) di Aceh, dimana para pelajar tersebut akan menjadi bagian dari anggota sosial masyarakat serta generasi yang akan melanjutkan budaya masyarakat.

Generasi Aceh kontemporer yang dibesarkan dalam suasana konflik sosial bersenjata telah menyebabkan permasalah dan kerusakan serius, baik secara fisik maupun secara mental. Maka dibutuhkan motivasi bagi generasi masa depan Aceh untuk keluar dari kondisi mental traumatic guna mencapai prestasi yang dapat memberi kontribusi positif bagi kelanjutan pem,bangunan yang lebih baik pasca konflik bersenjata.

Kemiskinan identik dengan kebodohan, ungkapan itu barangkali tidaklah terlalu jauh dari kenyataan kalau dilihat pada masyarakat di daerah pinggiran khususnya desa yang jauh dari jangkauan informasi, desa terpencil dan terisolir, yang kebanyakan orang menyebutnya desa tertinggal. Desa yang demikian mayoritas masyarakatnya hidup di bawah garis kemiskinan dengan tingkat SDM rata-rata rendah, hal ini salah satunya di pengaruhi oleh minimnya informasi yang masuk. Dengan demikian masyarakat yang hidup di desa seperti itu akan tertutup pengetahuannya. Salah satu ciri karakteristiknya adalah sikap apatis (masa bodoh) terhadap perkembangan yang terjadi di dunia luar. Energi berfikir mereka berputar-putar pada persoalan bagaimana pemenuhan kebutuhan 
dasar mereka tercukupi. Mereka tidak mampu berempati (membayangkan peran lain diluar dirinya) terhadap peran yang dianggap jauh di atasnya.

Dalam kaitannya dengan kurangnya pengetahuan seseorang maka akan berpengaruh pula pada pola pikir mereka. Baik berfikir untuk dirinya sendiri, lingkungan sekitarnya maupun dalam hal mendidik anak-anaknya. Artinya ada sebuah korelasi (hubungan) yang cukup signifikan antara tingkat pengetahuan dengan kepedulian sosial. Kalau saja ketidaktahuan atau kebodohan itu sudah melekat pada pola fikir seseorang maka segala langkah yang diambil bukan karena berdasarkan pengetahuan, akan tetapi lebih dikarenakan faktor kebiasaan yang dilakukan terus menerus, turun temurun.

Berangkat dari latar belakang tersebut di atas, maka penulis telah melakukan sebuah penelitian untuk mengungkapkan bagaimana pengaruh kemiskinan terhadap motivasi belajar anak-anak di Kota Langsa dalam pencapaian prestasi belajar siswa. Masalah yang akan dipaparkan dalam artikel ini adalah; Pertama, bagaimana pengaruh kemiskinan terhadap motivasi belajar siswa dan hubungan kemiskinan terhadap prestasi belajar. Kedua, faktor-faktor yang menjadi latar belakang penyebab kemiskinan di Kota Langsa serta pengaruhnya terhadap capaian prestasi akademik siswa.

Penelitian ini hanya menyelidiki pengaruh kemiskinan terhadap motivasi belajar siswa di Kota Langsa dalam pencapaian prestasi belajar siswa di Kota Langsa, dengan sampel 200 orang yang ambil pada tahun 2012. Dengan tujuan untuk mengetahui pengaruh kemiskinan terhadap motivasi, prestasi belajar siswa di Kota Langsa. Kemudian utuk mengetahui faktor-faktor yang melatarbelakangi penyebab kemiskinan.

Berdasarkan hasil penelitian Ernst R. Berndt The Practice of Economics Classic Contemporary, Addison Wesley Reading, Mass, 1991 melalui analisis regresi linier terdapat hubungan antara lama pendidikan dan rata-rata penghasilan per jam. Semakin lama pendidikan seseorang, semakin tinggi rata-rata penghasilan per jam yang didapat oleh tenaga kerja. Hasil penelitian pada negara di dunia ketiga memperlihatkan adanya korelasi positif antara tingkat pendidikan seseorang dengan tingkat pendapatannya. 
Analisis yang dikemukakan oleh Sajogyo kemiskinan pedesaan secara turun-temurun terkait dengan pola kepemilikan, pengolahan tanah, produktivitas tanah, struktur lapangan kerja yang sempit dan operasional tenaga kerja yang terbatas.) penelitian yang hampir sama pernah diteliti dari SMERU Risearch Institute, berdasarkan survei yang dilakukan pada 100 desa yang disponsori oleh World Bank dengan hasil studi menemukan bahwa terdapat hubungan negatif yang sangat kuat antara pertumbuhan dan kemiskinan. Pertumbuhan tidak mengurangi kemiskinan secara permanent. Pertumbuhan secara kontemporer dapat mengurangi kemiskinan. Pengurangan ketimpangan mengurangi kemiskinan secara signifikan. Dan memberikan hak atas property dan memberikan akses terhadap kapital untuk golongan masyarakat miskin dapat mengurangi kemiskinan.

\section{Motivasi}

Motivasi selalu dilihat sebagai isu sentral dalam psikologi kepribadian (Emmons, 1997) Setiap perbuatan mempunyai asas dan asas dari perilaku itu adalah motivasi, motivasi tidak sama dengan keperluan dan keinginan dasar, sebab keperluan dan keinginan adalah asas daripada motivasi. Motivasi merupakan diantara aspek psikologi yang paling banyak diteliti, Mclelland dalam Monks, Knoers, Haditono, (2004), misalnya seseorang yang tidak mempunyai tempat tinggal ia akan bekerja keras, bersungguh-sungguh untuk boleh memiliki rumah. Loftman, Weaver \& Wortman, (2000).

Meskipun motivasi bukanlah sesuatu masalah yang dapat diamati, tetapi ia adalah hal yang dapat disimpulkan adanya kerana sesuatu yang bisa kita lihat, rasakan dan saksikan, tentang adanya motivasi tersebut dalam setiap aktivitas yang dilakukan oleh seseorang dapat di buktikan dengan adanya semangat bekerja dalam melakukan suatu pekerjaan, semangat tersebut didorong oleh kekuatan dari dalam diri orang tersebut dan kekuatannya itu dapat berasal dari internal dan eksternal, pendorong inilah yang dimaksudkan dengan motivasi (Muljono 2008). Berbagai pendapat para pakar terhadap pemaknaan dari motivasi diantaranya seperti apa yang disebutkan oleh (Loftman, Weaver \& Wortman, 2000: 364). Motivasi sebagai: (state) which gives impetus to behaviour by arousing, sustaining, and directing it toward the attainment of 
goals. Pemberian dorongan terhadap tingkah laku dengan cara membangun, menyokong, dan memberikan arahan untuk pencapaian tujuan tertentu.

Disisi lain Allport dalam (Loftman, Weaver \& Wortman, 2000) menyatakan bahwa ada berbagai macam motivasi bergantung dari usaha dan pekerjaan yang dijalankan, motivasi manusia sangat banyak bukan satu atau dua macam saja, kepentingan asas manusia memang ada namun motivasi yang timbul selama hidup sangatlah banyak (Monks, Knoers, Haditono, 2004). Pada kenyataannya terdapat perbedaan antara motivasi internal dan eksternal. Motivasi dalaman adalah sesuatu yang memang diinginkan kerana seseorang menyukai benda tersebut, sesuatu dilakukan kerana hal atau perkara itu sendiri tanpa adanya tekanan, harapan ataupun paksaan dari luar, sedangkan motivasi eksternal adalah sesuatu dorongan yang berasal dari luar, orang melakukan sesuatu karena mengharapkan imbalan/reward dari luar atau juga kerana paksaan dari luar, seseorang yang melakukan hal yang terbaik agar semua orang kagum kepadanya adalah merupakan diantara contoh dari motivasi eksternal.

Secara Garis Besar motivasi terbagi menjadi motivasi eksternal dan internal, Motivasi eksternalmengacu pada diri sendiri, misalnya kegiatan belajar dihayati dan merupakan keperluan untuk memuaskan rasa ingin tahu. Motivasi eksternal mengacu pada faktor dari luar dirinya, misalnya ada anak yang sangat ingin menjadi terkenal kalangan kawan yang sederajat dengannya, kemudian dia belajar dengan lebih giat supaya terlihat lebih pandai. Kedua komponen ini bersifat kontekstual, artinya motivasi ini ada pada setiap diri orang yang berhubungan dengan suatu kegiatan yang dilakukannya, oleh kerana itu motivasi boleh berubah sesuai dengan perubahan waktu (Pintrich \& Schunk, 1996).

Seorang anak yang pada awalnya hanya belajar karena rasa ingin tahu, namun sejalan dengan reaksi positif dari sekitarnya, akhirnya ia belajar sungguh-sungguh untuk terus mendapatkan reaksi yang positif dari lingkungan tersebut. Bagi para pelajar yang membuat tugas dengan alasan internal tidak hanya perlu penghayatan, tetapi juga perlu memperlancarkan proses belajar dan pencapaian prestasi akademik yang lebih baik. (Gottfried dalam 
Pintrich \& Schunk, 1996). Dengan adanya motivasi internal maka akan memudahkan pelajar untuk melakukan aktivitas-aktivitas yang nantinya akan meningkatkan proses belajar dengan cara memperhatikan arahan yang diberikan, banyak berlatih dengan materi pelajaran, mengorganisir pengetahuan baru, menghubungkan pengetahuan yang baru dengan pengetahuan yang telah dimiliki serta menerapkan keterampilan dan pengetahuan tersebut.

Ada empat hal yang dapat menimbulkan motivasi internal yaitu: tantangan, keingintahuan, pengetahuan dan fantasi, yang kesemuanya ini akan muncul apabila adanya aktivitas yang menantang atau tugas yang susah untuk dikerjakan, selain itu juga bergantung kepada keingintahuan para pelajar pada kegiatan yang mengejutkan dan berlawanan dengan apa yang diketahuinya sebelum ini, tidak lazim atau berbeda dengan ide ataupun faham yang diketahui sebelumnya. (Lepper \& Hodell dalam Pintrich \& Schunk, 1996).

Beberapa peneliti lain mempunyai pendapat yang berbeda tentang motivasi, misalnya Atkinson \& Faether (Pintrich \& Schunk, 1996). Menyatakan bahwa situasi haruslah kompetitif sebelum munculnya motivasi dengan dua komponen yaitu keinginan untuk sukses / the need to achieve success/ achievement motivation/motive for success serta keinginan untuk mengelakkan kegagalan/ the need to avoid failure.

Seseorang yang memiliki dorongan sukses akan mempunyai minat yang lebih besar untuk bekerja lebih keras sehingga ia pantas diberikan tugas yang menantang berbanding dengan orang yang memiliki motive to avoid failure. Sedangkan menurut Mc Clelland dan Atkinson (Djiwandono, 2002), motivasi yang paling penting dalam psikologi pendidikan adalah motivasi berprestasi, dimana seseorang kerap berjuang untuk mencapai sukses atau memilih suatu kegiatan yang berorientasi untuk tujuan sukses. Lebih lanjut Asnawi (2002) yang menyokong Teori McClelland menyatakan bahwa motivasi yang ada dalam diri manusia dapat dipelajari dari lingkungan sosial.

Menariknya Purwanto (2007: 70) dan Monks, Knoers \& Haditono (2004), menyatakan bahwa ada tiga fungsi dari motivasi, 
yakni: Pertama, mendorong manusia untuk berbuat atau bertindak, motivasi sebagai penggerak atau mesin yang akan memberikan energi (kekuatan) kepada seseorang untuk melakukan suatu tugas dalam kegiatan belajar, motivasi memberikan dorongan kepada para siswa untuk berusaha keras dalam menguasai materi yang diajarkan oleh guru kepada siswa, mereka harus berusaha untuk menyerap bahan pelajaran tersebut. Kedua, mengarahkan perbuatan. Yaitu adanya suatu tujuan atau cita-cita dengan cara mengarahkan pekerjaan, motivasi menghindari lari dari asal yang telah ditetapkan, semakin jelas tujuan dari pekerjaan yang dijalankan, maka semakin jelas pula jalan mana yang akan ditempuh. Seorang siswa akan lebih terarah kegiatannya jika ia memiliki motivasi yang tinggi untuk belajar, meskipun kadang mereka membutuhkan aktivitas selingan untuk me-refresh (menyegarkan) pikiran mereka sendiri, namun dengan motivasi yang kuat akan mengembalikan mereka ketujuan asli mereka dengan arah pencapaian yang benar dalam pencapaian tujuan belajar. Ketiga, meneliti tingkah laku, motivasi juga dapat meneliti praktek apa yang sesuai dan tidak sesuai dalam pencapaian tujuan mereka, misalnya "seseorang yang benar-benar ingin mencapai kegemilangan akademis maka mereka tidak akan membuang waktu, sebab hal tersebut tidak sesuai dengan tujuan mereka" (Purwanto, 2007:71)

Meskipun di dalam proses belajar, terdapat tingkat perbedaan tingkat motivasi diantara siswa, namun demikian secara umum motivasi adalah merupakan dorongan dalam kegiatan belajar, motivasi yang dibutuhkan siswa dalam belajar meliputi: Pertama, mencari dan mendapatkan bahan mengenai materi yang akan dipelajari. Kedua, menyerap dan memahami materi yang diajarkan serta mempraktekkannya. Ketiga, mengubah informasi yang didapat ini menjadi suatu hasil (pengetahuan, perilaku, keterampilan, sikap dan kreatifitas). Keempat, menerapkan pencapaian yang dipelajari tersebut di dalam kehidupan (Sukadji, 2000)

Pelajar yang termotivasi menunjukkan minat dan komitmen ketika belajar yang dapat dilihat ketika mereka mulai dan mempertahankan aktifitas belajar. Pelajar yang termotivasi secara internal menggunakan beberapa kombinasi dari beberapa perilaku, meliputi: membaca secara strategis, memahami secara mendalam, dan 
terkendali (turner, 1995). Sukadji (2000) menyatakan bahwa: Motivasi belajar adalah dorongan untuk membuat pelajar melakukan kegiatan belajar, termasuk memotivasi diri mereka untuk mendapatkan hasil kelulusan dan motivasi untuk melanjutkan studi ke pendidikan yang lebih tinggi.

Menurut Woolfolk (1993) juga diperlukan strategi untuk meningkatkan motivasi belajar agar siswa merasa percaya diri bahwa kemampuannya dapat meningkat prestasi akademik serta menghargai nilai belajar dan tetap yakin selama peroses belajar. Menurut Woolfolk beberapa langkah diperlukan dalam upaya untuk meningkatkan motivasi belajar antara lain: Pertama, memenuhi kebutuhan dasar siswa yaitu ruang belajar yang nyaman, guru yang kompeten dan mendukung dalam belajar, serta tugas-tugas yang seharusnya dan menantang namun tidak terlalu susah untuk dikerjakan. Kedua, membangun kepercayaan diri dan harapan positif yaitu menetapkan tujuan belajar yang tetap, jelas dan dapat dicapai, menjelaskan bahwa prestasi akademik dapat ditingkatkan, memberi contoh solusi masalah. Ketiga, menunjukkan arti belajar yaitu menghubungkan kegiatan belajar dengan kebutuhan siswa dan manfaat belajar masa depan, membuat aktifitas yang menarik minat siswa, menimbulkan rasa ingin tahu, membuat tugas yangmenyenangkan, menciptakan suasana akrab dan kekeluargaan. Keempat, membantu siswa terfokus pada tugas yaitu memberikan banyak kesempatan merespon dan berkreasi dalam tugas, mengurangi resiko tugas tanpa mengurangi nilai tugas, serta mengajarkan strategi belajar yang paling tepat. (Wool Folk, 1993).

Terkait dengan kemiskinan dimana salah satu ciri karakteristiknya adalah sikap apatis (masa bodoh) terhadap perkembangan yang terjadi di dunia luar. Energi berfikir mereka berputar-putar pada persoalan bagaimana pemenuhan kebutuhan dasar mereka tercukupi. Mereka tidak mampu berempati (membayangkan peran lain diluar dirinya) terhadap peran yang dianggap jauh di atasnya.

Dalam kaitannya dengan kurangnya pengetahuan seseorang maka akan berpengaruh pula pada pola pikir mereka. Baik berfikir untuk dirinya sendiri, lingkungan sekitarnya maupun dalam hal mendidik anak-anaknya. Artinya ada sebuah korelasi (hubungan) yang cukup signifikan antara tingkat pengetabuan dengan 
kepedualian sosial. Kalau saja ketidaktahuan atau kebodohan itu sudah melekat pada pola fikir seseorang maka segala langkah yang diambil bukan karena berdasarkan pengetahuan, akan tetapi lebih dikarenakan faktor kebiasaan yang dilakukan terus menerus, turun temurun. Seperti kalau boleh disimpulkan ada sebuah pola tentang kebodohan yang terus diwariskan ke anak cucunya dan itu akan sulit sekali untuk merubahnya. Dalam kontek ini kemiskinan menjadi salah satu variable yang berpengaruh terhadap motivasi anak untuk meraih prestasi akademik.

Berdasarkan hasil penelitian Ernst R. Berndt The Practice of Economics Classic Contemporary, Addison Wesley Reading, Mass, 1991 melalui analisis regresi linier terdapat hubungan antara lama pendidikan dan rata-rata penghasilan per jam. Semakin lama pendidikan seseorang, semakin tinggi rata-rata penghasilan per jam yang didapat oleh tenaga kerja. Hasil penelitian pada negara di dunia ketiga memperlihatkan adanya korelasi positif antara tingkat pendidikan seseorang dengan tingkat pendapatannya.

Analisis yang dikemukakan oleh Sajogyo kemiskinan pedesaan secara turun-temurun terkait dengan pola kepemilikan, pengolahan tanah, produktivitas tanah, struktur lapangan kerja yang sempit dan operasional tenaga kerja yang terbatas.) penelitian yang hampir sama pernah diteliti dari SMERU Risearch Institute, berdasarkan survei yang dilakukan pada 100 desa yang disponsori oleh World Bank dengan hasil studi menemukan bahwa terdapat hubungan negatif yang sangat kuat antara pertumbuhan dan kemiskinan. Pertumbuhan tidak mengurangi kemiskinan secara permanent. Pertumbuhan secara kontemporer dapat mengurangi kemiskinan. Pengurangan ketimpangan mengurangi kemiskinan secara signifikan. Dan memberikan hak atas property dan memberikan akses terhadap kapital untuk golongan masyarakat miskin dapat mengurangi kemiskinan.

\section{Metode Penelitian}

Penelitian ini merupakan penelitian kualitatif dengan teknik survey. Karena jumlah sampel yang agak besar, juga menggunakan teknikteknik lain seperti teknik observasi, wawancara dan projektif. Metode tinjauan adalah kaidah yang terbaik untuk mengambil data dari 
suatu populasi yang besar melalui teknik persampelan penelitian (Babbie : 2001). Dengan teknik tersebut penulis akan mengalisis variabel utama yaitu dampak kemiskinan terhadap motivasi dan prestasi belajar serta hubungan keduanya pada kasus siswa penerima beasiswa miskin di Kota Langsa. Penelitian ini dilakukan pada Sekolah Menengah Atas (SMA) dalam wilayah Kota Langsa di 4 (empat) Kecamatan yaitu Kec. Langsa Kota, Kec. Langsa Barat, Kec. Langsa Baro, dan Kec. Langsa Timur.

Dalam kajian ini yang akan digunakan sebagai alat ukur motivasi adalah kuisioner motivasi belajar instrinstik motivasi yang disadur dari Ryan (2001) dan Harlyna (2004). Yang disebut dengan instrinstic motivation Inventory (IMI).

Kesemuaan skala ini akan di ukur berdasarkan skala diktomus dengan jawaban ya/tidak jika pada pertanyaan positif jawaban ya mendapat nilai 1(satu) sedang tidak mendapat nilai 0 (Nol),apabila dalam pertanyaan negatif akan dinilai sebaliknya jawaban ya mempunyai jumlah nilai 0 ( $\mathrm{Nol})$, sedang jawaban tidak mempunyai jumlah nilai 1 (satu). Selanjutnya skor akan diberi jumlah nilai dengan tiga kriteria:

- Motivasi Tinggi $(\mathrm{T})=67-100 \%$

- Motivasi Menengah (S) $=34-66 \%$

- Motivasi Rendah (R) $=0-33 \%$

Data yang diperoleh dari hasil penyebaran kuisioner/ angket kemudian ditabulasikan dan dianalisis dengan menggunakan SPSS Vers.13.

Populasi dalam penelitian ini adalah masyarakat miskin di Kota Langsa. Adapun sampel dari penelitian ini adalah anak-anak penerima beasiswa miskin di Kota Langsa. Penelitian ini hanya mengambil 200 orang pelajar saja sebagai sampel penelitian, dengan merujuk apa yang disampaikan oleh (Sudjana : 1992) bahwa sampel merupakan sebagian dari populasi yang dipilih dengan teknik random dan dianggap representatif, artinya karakteristik populasi tercermin dalam sampel yang diambil.

Sumber data yang diperoleh dalam penelitian ini terbagi kepada tiga bagian, yaitu: Pertama, tingkat kemiskinan di Aceh 
dan Kota Langsa, data ini diperoleh melalui riset yang telah dilakukan oleh BPS pada tahun 2010 s/d 2011, hasil penelitian BPS yang di publikasikan melalui Aceh dalam angka dan situs resmi BPS di www.aceh.bps.go.id . Terkait dengan data motivasi belajar penulis telah menyebarkan angket instrinstic motivation Inventory (IMI) dalam bentuk kuisioner motivasi belajar instrinstik motivasi yang disadur dari Ryan (2001) dan Harlyna (2004) dengan cara diberikan kepada sampel penelitian melalui guru kelas masingmasing. Selanjutnya menyangkut dengan prestasi akademik pelajar penulis telah mengumpulkan seluruh hasil belajar siswa dalam satu semester.

\section{Analisis}

Tabel 1

Hubungan Motivasi Belajar dengan Prestasi Belajar Di Luar Kota Langsa

\begin{tabular}{lll}
\hline & & PrestasiAkademik \\
\hline MotivasiBelajar & Pearson Correlation & 0.52 \\
& Sig. (2-tailed) & 0.00 \\
& $\mathrm{~N}$ & 100 \\
\hline
\end{tabular}

** = Signifikanpadatingkat 0.01

* = Signifikanpadatingkat 0.05

$\mathrm{N}=$ Jumlah sample

Tabel di atas Pearson correlation terhadap tingkat motivasi belajar dan prestasi belajar siswa di luar Provinsi Aceh dengan jumlah sampel penelitian sebanyak 100 orang menunjukkan bahwa nilai $(r=0,52$ signifikan pada tingkat 0,01 . Nilai ini menunjukkan hubungan positif yang cukup signifikan antara motivasi belajar dengan prestasi belajar, hal tersebut berarti jika motivasi belajar meningkat maka prestasi belajar juga akan meningkat Uji dilakukan 2 tailed (dua arah) karena yang akan dicari adalah ada atau tidaknya hubungan antara kedua variabel. Oleh karena nilai tersebut signifikan <0,05 maka Ho ditolak, berarti ada hubungan antara variabel X (Motivasi belajar) dan Y (Perolehan belajar). 
Motivasi selalu dilihat sebagai isu sentral dalam psikologi kepribadian (Emmons, 1997). Setiap perbuatan memiliki landasan dan asas dari perilaku itu adalah motivasi, motivasi tidak sama dengan keperluan dan keinginan dasar, sebab keperluan dan keinginan adalah asas daripada motivasi. Hasil uji statistic ini memperkuat teori bahwa motivasi diantara aspek psikologi yang paling berpengaruh terhadap sebuah tindakan. Diantaranya seperti apa yang disebutkan oleh (Loftman, Weaver \& Wortman, 2000: 364). Motivasi sebagai: (state) which gives impetus to behaviour by arousing, sustaining, and directing it toward the attainment of goals. Pemberian dorongan terhadap tingkah laku dengan cara membangun, menyokong, dan memberikan arahan untuk pencapaian tujuan tertentu.

Tabel 2

Hubungan Dimensi-Dimensi Motivasi Belajar dengan Prestasi Akademik

\begin{tabular}{llllll}
\hline Prestasi akademik & $\begin{array}{l}\text { Interest } \\
\text { /enjoymen }\end{array}$ & $\begin{array}{l}\text { Perceived } \\
\text { copetence }\end{array}$ & $\begin{array}{l}\text { Presure } \\
\text { /tension }\end{array}$ & $\begin{array}{l}\text { Perceived } \\
\text { Choice }\end{array}$ & $\begin{array}{l}\text { Valuel } \\
\text { Usefulness }\end{array}$ \\
\hline Pearson corelatioan & $0.33^{* * *}$ & $0.34^{* *}$ & $0.66^{* * *}$ & $0.39^{* *}$ & $0.40^{* *}$ \\
sig. (2- tailed) & 0.00 & 0.00 & 0.00 & 0.00 & 0.00 \\
$N$ & 500 & 500 & 500 & 500 & 500 \\
\hline
\end{tabular}

** = Signifikanpadaaras 0.01

* = Signifikanpadaaras 0.05

$\mathrm{N}$ = Jumlah sample

Tabel di atas Pearson correlation terhadap tingkat dimensi motivasi belajar dengan prestasi belajar pada seluruh sampel penelitian sebanyak 500 orang menunjukkan hasil sebagai berikut: Interest/enjoyment berhubungan dengan prestasi belajar nilai sebesar $(\mathrm{r}=0,33)$. Signifikan pada tingkat 0,01 , perceived Competence berhubungan dengan prestasi belajar nilai sebesar $(r=.34)$, signifikan pada tingkat 0,01 , pressure/tension berhubungan dengan prestasi belajar nilai sebesar $(r=0.36)$, signifikan pada tingkat 0,01 , perceived choice berhubungan dengan prestasi belajar nilai sebesar $(r=0,39)$ signifikan pada tingkat 0,01 Value/usefulness berhubungan dengan prestasi akademis nilai sebesar $(r=.40)$ signifikan pada tingkat 0,01 . 
Nilai ini menunjukkan hubungan positif yang cukup signifikan antara setiap dimensi motivasi belajar dengan prestasi belajar, hal ini berarti jika setiap dimensi motivasi belajar meningkat maka prestasi belajar juga akan meningkat. Uji dilakukan 2 tailed (2 arah) karena yang akan dicari adalah ada atau tidaknya hubungan kedua variabel tersebut. Karena nilai tersebut signifikan $<0,05$ maka hal tersebut berarti bahwa terdapat hubungan antara variabel X (setiap dimensi dalam Motivasi Belajar) danY(Perolehan belajar).

Seorang anak yang pada awalnya hanya belajar karena rasa ingin tahu, namun sejalan dengan reaksi positif dari sekitarnya, akhirnya ia belajar sungguh-sungguh untuk terus mendapatkan reaksi yang positif dari lingkungan tersebut. Bagi para pelajar yang membuat tugas dengan alasan internal tidak hanya perlu penghayatan, tetapi juga perlu memperlancarkan proses belajar dan pencapaian prestasi akademik yang lebih baik. (Gottfried dalam Pintrich \& Schunk, 1996). Dengan adanya motivasi internal maka akan memudahkan pelajar untuk melakukan aktivitas-aktivitas yang nantinya akan meningkatkan proses belajar dengan cara memperhatikan arahan yang diberikan, banyak berlatih dengan materi pelajaran, mengorganisir pengetahuan baru, menghubungkan pengetahuan yang baru dengan pengetahuan yang telah dimiliki serta menerapkan keterampilan dan pengetahuan tersebut.

Pelajar yang termotivasi menunjukkan minat dan komitmen ketika belajar yang dapat dilihat ketika mereka mulai dan mempertahankan aktifitas belajar. Pelajar yang termotivasi secara internal menggunakan beberapa kombinasi dari beberapa perilaku, meliputi: membaca secara strategis, memahami secara mendalam, dan terkendali (Turner, 1995).

\section{Tahap Motivasi Belajar Siswa}

Untuk menjawab pertanyaan apakah ada perbedaan tingkat motivasi belajar yang signifikan antar pelajar dalam wilayah Kota Langsa, maka dilakukan pengujian T-test dengan menggunakan SPSS versi 0.13 diperoleh hasil sebagai berikut: 
Tabel 3

Nilai Min Uji Motivasi Belajar Siswa.

\begin{tabular}{clccc}
\hline $\begin{array}{c}\text { Motivasi } \\
\text { Belajar }\end{array}$ & \multicolumn{1}{c}{ Pelajar } & Mean & $\begin{array}{c}\text { Standar } \\
\text { Deviasi }\end{array}$ & $\begin{array}{c}\text { Standar } \\
\text { Eror }\end{array}$ \\
\hline Kota Langsa & Pelajar Miskin & 17.3452 & 2.437 & 0.122 \\
& Bukan Pelajar Miskin & 18.1992 & 3.869 & 0.3877 \\
\hline
\end{tabular}

Dari tabel di atas dapat diketahui bahwa nilai min motivasi belajar siswa luar Kec. Langsa Kota adalah $(\min =18.20$ Sp. 3.869) sedangkan nilai min motivasi belajar siswa di Kota Langsa adalah $(\min =17.35 \mathrm{Sp} 2.437)$ hal ini berarti bahwa: parasa kesehatan mental pelajar luar Aceh lebih tinggi dibandingkan siswa Aceh artinya kesehatan mental pelajar Aceh lebih rendah dibandingkan mahasiswa luar Aceh. untuk melakukan uji apakah kedua varian sampel sama atau berbeda maka perlu dilakukan uji $\mathrm{T}$ test hasil uji menunjukkan:

Tabel 4

Levene's Test,Independent Samples Test Motivasi Belajar

\begin{tabular}{|c|c|c|}
\hline & $\begin{array}{l}\text { Equal variance } \\
\text { Assumend }\end{array}$ & $\begin{array}{l}\text { Equal variance } \\
\text { Not Assumend }\end{array}$ \\
\hline Levene's test for $F$ & 32.30 & \\
\hline Equality of Variances sig. & 0.00 & \\
\hline t-test for equality of $t$ & -2.746 & -2.105 \\
\hline mean $\quad d f$ & 498 & 199.322 \\
\hline sig. (2-tailed) & 0.006 & 0.037 \\
\hline Mean difference & -0.854 & -0.854 \\
\hline Std. error difference & 0.311 & 0.405 \\
\hline $95 \%$ confidence in & -1.146 & -1.657 \\
\hline Of the difference upper & -0.243 & -0.501 \\
\hline
\end{tabular}

Dari tabel di atas diketahui bahwa perbedaan tingkat motivasi belajar tersebut signifikan pada tingkat 0,05 yang berarti bahwa terdapat perbedaan yang signifikan antara tingkat motivasi belajar siswa di Kota Langsa dan siswa luar Kota Langsa. 
Hubungan Motivasi Belajar dan Prestasi Akademik Pelajar di Kota Langsa

\author{
Table 5
}

Hubungan Prestasi Akademik dan Motivasi Belajar di wilayah

Langsa

\begin{tabular}{llc}
\hline Correlation & & Motivasi Belajar \\
\hline Kesihatan Mental & Correlation & $0.36^{* * *}$ \\
& Sig. ( 2-tailed) & 0.00 \\
& $\mathrm{~N}$ & 400 \\
\hline
\end{tabular}

* = Signifikan pada aras 0.01

* = Signifikan pada aras 0.05

$\mathrm{N}=$ Jumlah sample

Tabel di atas menunjukkan bahwa nilai hubungan antara motivasi belajar dan prestasi akademis siswa di kota langsa adalah $(\mathrm{r}=0,036)$ pada tingkat 0,05 hal ini menunjukkan bahwa ada hubungan yang signifikan antara prestasi akadmis dan motivasi belajar dalam wilayah kota langsa pada tingkat signifikan 0, 05, pernyataan ini berarti bahwa ada hubungan yang signifikan antara prestasi akademik dan motivasi belajar pada siswa dalam wilayah Kota Langsa.

Hal tersebut berarti jika motivasi belajar meningkat maka prestasi akademik siswa juga akan meningkat. uji dilakukan 2 tailed (bilateral) karena yang akan dicari adalah ada atau tidaknya hubungan antara kedua variabel, oleh karena nilai tersebut signifikan $<0,05$ maka Ho ditolak, berarti ada hubungan antara variabel $\mathrm{X}$ (motivasi belajar) dan Y (prestasi akademik siswa ).

\title{
Hubungan Setiap Dimensi Motivasi Belajar Dengan Prestasi
} Akademik

Untuk menjawab pertanyaan apakah ada hubungan yang signifikan antara dimensi motivasi belajar dengan prestasi akademik siswa dalam seluruh wilayah penelitian akan dilakukan uji corelasi antara nilai setiap dimensi kesehatan mental dan nilai prestasi akademik siswa dalam seluruh wilayah penelitian hasil penelitian 
menunjukkan temuan sebagai berikut;

Tabel 5

Hubungan Antara Setiap Dimensi Motivasi Belajar Dengan

Prestasi Akademik

\begin{tabular}{llllll}
\hline Prestasi akademik & $\begin{array}{l}\text { Interest/ } \\
\text { enjoymen }\end{array}$ & $\begin{array}{l}\text { Perceived } \\
\text { copetence }\end{array}$ & $\begin{array}{l}\text { Presure } \\
\text { /tension }\end{array}$ & $\begin{array}{l}\text { Perceived } \\
\text { Choice }\end{array}$ & $\begin{array}{l}\text { Valuel } \\
\text { Usefulness }\end{array}$ \\
\hline Pearson corelatioan & $0.33^{* *}$ & $0.34^{* *}$ & $0.66^{* * *}$ & $0.39^{* *}$ & $0.40^{* *}$ \\
sig. (2-tailed) & 0.00 & 0.00 & 0.00 & 0.00 & 0.00 \\
$N$ & 500 & 500 & 500 & 500 & 500 \\
\hline
\end{tabular}

* = Signifikan pada aras 0.01

* = Signifikan pada aras 0.05

$\mathrm{N}$ = Jumlah sampel

Tabel di atas menunjukkan bahwa hubungan setiap dimensi motivasi belajar dengan prestasi akademik siswa di seluruh sampel penelitian menunjukkan hasil sebagai berikut: Interest/enjoyment berhubungan dengan prestasi akademik siswa nilai sebesar $(\mathrm{r}=$ $0,33)$. signifikan pada tingkat 0,01 , perceived competence berhubungan dengan prestasi akademik siswa nilai sebesar $(r=.34)$, signifikan pada tingkat 0,01 , pressure/tension berhubungan dengan prestasi akademik siswa nilai sebesar $(r=0.36)$, signifikan pada tingkat 0,01 , perceived choice berhubungan dengan prestasi akademik siswa nilai sebesar $(r=0,39)$ signifikan pada tingkat 0,01 value/usefulness berhubungan dengan pencapaian akademis nilai sebesar $(r=.40)$ signifikan pada tingkat 0,01 .

Nilai ini menunjukkan hubungan positif yang cukup signifikan antara setiap dimensi motivasi belajar dengan prestasi akademik siswa, hal ini berarti jika setiap dimensi motivasi belajar meningkat maka prestasi akademik siswa juga akan meningkat pula, uji dilakukan 2 tailed ( 2 arah) karena yang akan dicari adalah ada atau tidaknya hubungan kedua variabel tersebut, oleh karena nilai tersebut signifikan $<0,05$ maka hal tersebut berarti bahwa terdapat hubungan antara variabel X (setiap dimensi dalam motivasi belajar) dan Y (prestasi akademik siswa). 
Pengarub Motivasi belajar terhadap prestasi akademik di KotaLangsa

Untuk menjawab pertanyaan apakah ada sumbangan kesehatan mental terhadap prestasi akademik siswa di wilayah Kota Langsa? maka perlu dilakukan uji ANOVA dan uji regresi dengan menggunakan SPSS versi 0.13 diperoleh hasil sebagai berikut:

H0 $=$ Kesehatan mental pelajar di Wilayah Kota Langsa tidak berpengaruh terhadap prestasi akademik pelajar.

Tabel 6

ANOVA Varians Kesehatan Mental Terhadap Prestasi Akademik di Langsa

\begin{tabular}{lllllll}
\hline & & $\begin{array}{l}\text { Jumlah } \\
\text { Kuasa dua }\end{array}$ & Df & $\begin{array}{l}\text { Min } \\
\text { Kuasa dua }\end{array}$ & F & Sig \\
\hline Kesihatn & $\begin{array}{l}\text { Regresion } \\
\text { Mental }\end{array}$ & 11.64 & 1 & 11.64 & 14.14 & .000 \\
& residual & 80.66 & 98 & 0.82 & & \\
& total & 92.29 & 99 & & & \\
\hline
\end{tabular}

a. Variabel bebas(Constant): kesehatan mental

b. VariabelTerikat: motivasi belajar

Tabel 7

regresi (enter) Untuk variabel Motivasi Belajar mempengaruhi prestasi akademik

\begin{tabular}{llllllll}
\hline Model 1 & B & Ralat piawai & Beta & t & sig & $\mathrm{R}^{2}$ & Sumbangan \\
\hline Pemelar & 0.42 & 0.76 & & - & 0.58 & 0.13 & $13 \%$. \\
Desain & 0.16 & 0.04 & 0,36 & 0.56 & 0.00 & & \\
& & & & 5.76 & & & \\
\hline
\end{tabular}

Pada tabel anova menunjukkan variabel bebas menjadi prediksi keatas variabel ubahan bersandar yaitu kesehatan mental ditampilkan $\mathrm{F}$ hitung $(\mathrm{F}=14.14)$ dan Sig $=0.00<0.05)$ nilai beta dan kontribusi ditampilkan dalam tabel 4.66 kesehatan mental sebagai peramal memberikan nilai beta $=0.36 \mathrm{t}=-0.56$, sig $=0.00 .>0.05$ dan R2 $=0.13$ temuan ini berarti bahwa kesehatan mental siswa berkontribusi atas prestasi akademis siswa sebesar 13\% variasi yang terjadi terhadap tinggi atau rendahnya prestasi akademik siswa disebabkan kesehatan mental siswa, sedangkan sisanya dipengaruhi 
faktor lain kesimpulan yang dapat diambil dari hasil analisis ini adalah setiap kenaikan 1 unit variabel kesehatan mental pelajar (X) dapat meningkatkan 0.16 pula indeks motivasi belajar ditambahkan 3.399, dari temuan regresi tersebut dapat dibuat persamaan regresi sebagai berikut:

$\mathrm{Y}=\mathrm{v}=0.42+0.16+0.13$

$\mathrm{Y}=$ Kesehatan mental pelajar

$\mathrm{X}=$ Prestasi akademik

$\mathrm{R}^{2}=.13$

Pemelar $($ counstan $)=0.42$

Ralat piawai (standard eror) 0.76

Maka dapat dikatakan bahwa motivasi belajar memiliki pengaruh yang signifikan terhadap prestasi akademik pelajar.

\section{Kesimpulan}

Tingkat kemiskinan pada masyarakat Kota Langsa sangat mempengaruhi motivasi anak-anak untuk menempuh pendidikan. Kemiskinan secara signifikan berimbas pada motivasi belajar siswa dan tingkat prestasi akademis siswa di Kota Langsa. Dengan kata lain bahwa tingkat pendidikan siswa, motivasi belajar siswa sangat dan kesadaran keluarga akan pentingnya pendidikan sangat bergantung pada kondisi ekonomi keluarga. Keluarga yang kondisi ekonomi lemah cenderung mengabaikan pendidikan anak-anaknya karena pemenuhan kebutuhan sehari-hari dalam keluarga lebih penting dari pendidikan anakya.

\section{Daftar Pustaka}

Asnawi S. 2002. Teori Motivasi, Jakarta: Studia Press

Atkinson, J.W. \& Raynor, J.O. 1978. Personality, Motivation, and Achievement New York: John Willey \& Sons.

Babbie, E.M. 2001. The practice of social research.Ed.. ke-9. New York wadsworth thomson learning.

Badan Pusat Statistik dan Bappeda Provinsi NAD. 2007. Buku saku Nanggroe Aceh Darussalam. Banda Aceh: BPS \& BAPPEDA Prov. NAD. 
Badan Pusat Statistik Provinsi NAD. 2007. Aceb dalam angka 2007. Banda Aceh: BPS

Badan Pusat Statistik Provinsi NAD. 2008. Aceh dalam angka 2008. Banda Aceh: BPS

D. Supardi. 1994. Masalah Pendidikan Untuk Anak Miskin, Majalah Prisma, Edisi Mei, Jakarta 56-61.

Djiwandono, S.E.W.2002. Phisikologi Pendidikan, Djakarta P.T Grasin

ELCAC Notes. 2004. "To Investee More-But Also Better-In Education". United Nation, Amerika Latin, 1-8.

Everyday Life: Toward a theory of emergent motivation. In J. E.Jacobs (Ed.), Developmental perspectives on motivation. Lincoln: University of Nebraska Press.

Gujarati, D, N.. 2003. "Basic Econometrics" Fourth Edition, McGraw hill University.

Kossylyn, Stephen M. \& Rosenberg, Robin S. 2003. Fundamental Psychology: The Brain, The Person, The World (2nd Ed.) international edition: Pearson

Kurniawati, A.. 2003. "Setitik Sinar di Antara Perbukitan", Lembar Sejarah, Pendidikan

McBrien, JL.. 2005.. Educational needs and barriers for refugee students in the United States:A review of the literature. Rev. Educ. Res.

Mikkelsen, B.. 2003. "Metode Penelitian Partisipatoris dan Upayaupaya Pemberdayaan", Yayasan Obor Indonesia, Jakarta.

Monks, F.J, Knoers, A.M.P \& Haditiono, Siti Rahayu. 2004. Psikologi Perkembangan: Pengantar dalam Berbagai bagiannya (Ed. Kelima), Jogjakarta: UGM Press.

Muljono notosodirjo \& latipun. 2007. Kesehatan mental konsep dan peneraapan. edisi ke-empat cetakan kelima, Malang Universitas Muhammaddiah

Nidzamul Iqtishadi fil Islam. 1998. Beirut: Darul Ummah

Pintrich, P.R. \& Schunk, D.H.. 1996. Motivation in Education, New Jersey: Prentice Hall, Inc.

Undang-undang Republik Indonesia nomor 20 tahun 2003. 2003. tentang Sistem Pendidikan Nasional, pasal 3 ayat 1. CV. 
Madya Duta: Jakarta,

WHO. 2001, A Public Health Approach To Mental Health, WHO

.......2008 , A Public Health Approach To Mental Health, WHO

Wool Folk A.E.. 1993. Educational Psychology (5 th Ed.) Boston:

Allyn \& Bacon

Wortman, Camille B., Loftus Elizabth F.,\& Weaver, Charles (2000)

Psychology (5th Ed.) International Edition: Mc Graw Hill Company

Zayfert, Claudia \& Becker. 2007. Cognitive-Behavioral Therapy for PTSD a case formulation approach, The Guilford Press: New York London. 